\title{
2010: UMA ODISSÉIA ESPORTIVA
}

Luis Fernando Pozzi

Parodiando Martin Luther King, eu tive um sonho: decidido a passar um fim de semana divertido com a minha família, optei por um espetáculo cada vez mais concorrido na grande metrópole paulistana: assistir a um jogo do meu time, o Corinthians S.A., contra a Inter de Milão, pela Liga Mundial Interclubes, ou Opel Cup, como é mais conhecida.

Como acionista do Corinthians e detentor de um assento reservado por toda a temporada 2009/2010, decido respirar futebol por dois dias, hospedando-me no complexo turístico/esportivo do clube, o Corinthians Nike Meliá Center ${ }^{1}$, onde o clube manda seus jogos, no sábado pela manhã.

Logo ao chegar, estaciono meu carro num lugar coberto e reservado para mim, deixo minhas coisas no quarto e vou tomar café da manhã no restaurante temático do complexo, repleto de troféus, camisas, chuteiras, bolas, fotos e charges alusivas às grandes con- quistas do clube. Neste ambiente, todo decorado em preto e branco, minha esposa, meu casal de filhos e eu nos sentamos a uma mesa, tendo como companhia, além de outros acionistas e turistas de passagem pela cidade, os próprios jogadores, concentrados para a partida do dia seguinte.

Uma vez terminado o café, os jogadores colocam-se à disposição dos presentes para uma sessão de autógrafos. Solícitos, atendem a todos, preocupando-se especialmente em atender às crianças e responder às suas dúvidas, já que todos no clube-empresa sabem que a continuidade do sucesso dentro de campo depende das gerações futuras de torcedores, o que, por sua vez, reflete nos resultados fora de campo. Ao final do café, meus filhos saem com seus troféus: a camisa do clube assinada por seus ídolos.

Após esse contato inicial com seus ídolos, os hóspedes têm uma série de alternativas, desde as mais tradicionais, como piscinas, gincanas e atividades físicas, que visam agradar aqueles que nem ligam para o futebol, mas buscam diversão, até aquelas voltadas para os torcedores mais fanáticos, como acompanhar o último treino do clube antes do jogo ou participar de clínicas na escolinha de futebol, onde ídolos do passado do clube passam dicas de sua "arte" para a garotada.

Enquanto meus filhos aprimoram seus "dotes futebolísticos" na escolinha, aproveito para dar uma passadinha na megastore Nike Passion ${ }^{2}$, onde encontro todo e qualquer produto possível e imaginável com o distintivo e as cores do clube, dispostos de maneira visualmente tão atrativa, que é impossível resistir. Obviamente, a Nike tem um espaço de destaque, onde vende com exclusividade todos os artigos por ela fabricados, desde bola até relógios, óculos e pôsteres, passando pelos uniformes oficiais do clube. 
As marcas dos demais fabricantes são mais uma garantia de qualidade, o que me faz levar um presente para cada membro da família. Assustado com o valor dessa despesa inesperada, resta-me um consolo: usando o meu cartão de afinidade, tenho direito a um desconto de $10 \%$, além de acumular pontos que servirão de desconto na compra dos ingressos para a temporada seguinte.

Ao final da tarde, encontramos nossos lugares reservados na sala de imprensa, onde os jogadores e a comissão técnica explicarão aos jornalistas como foi a preparação e quais as expectativas para o jogo. Terminada a coletiva, mais uma oportunidade para interagirmos com os craques.

Após jantarmos e despacharmos nossos futuros craques para a cama, eu e minha esposa decidimos dar uma passadinha no Heineken Black \& White Cafe, bar temático que, além da decoração futurista e aconchegante, dos pratos e drinks com nomes dos craques do passado e do presente, das atendentes vestidas com uniformes estilizados do clube e com um pista de dança com o formato do distintivo do clube, conta com jogos eletrônicos interativos e mesas para os amantes do eterno futebol de botão. O bar é estrategicamente localizado, o que possibilita uma visão panorâmica do campo de jogo, para quem não quer se dar ao trabalho de descer ao campo.

No dia seguinte, ainda encontramos tempo para mais uma atividade antes do grande espetáculo: uma visita ao museu interativo Microsoft Nação Corinthiana, onde as pessoas podem acessar a história do clube em estações multimídia, com fotos, imagens e sons das grandes glórias esportivas.

Finalmente, chega o horário do jogo, e os hóspedes do complexo são levados aos seus assentos por uma entrada independente. Apesar da transmissão do jogo inclusive para São Paulo, pelo sistema de pay-per-view, o estádio está totalmente tomado, aliás como em quase todos os jogos do time, já que as vendas antecipadas de ingressos para a temporada respondem pela grande maioria das receitas totais de bilheteria.

Grande parte dos torcedores chegaram ao estádio de metrô ${ }^{3}$, já que há uma estação que desembarca na porta do estádio. Para os que vieram de carro, estacionamentos subterrâneos transformaram os flanelinhas em espécimes extintas, que sobrevivem apenas como personagens de ficção nas histórias contadas pela nossa geração. Já dentro dos estádios, os torcedores contam com várias opções de fastfood, além do Black \& White Cafe. Complementando o cenário, banheiros limpos, stands com pequenas lembranças do time, seguranças particulares, serviço impecável de informações...

Apesar do temporal que desaba lá fora - certas coisas nunca mudam -, o clima dentro do estádio é agradável, graças ao sistema de cobertura móvel do teto e de ar condicionado. Antes de os times entrarem em campo e da execução dos hinos nacionais, os telões de alta definição encarregam-se de comandar os gritos de guerra da torcida e o compasso das músicas, ao mesmo tempo em que todas as empresas que tenham alguma associação com o evento aproveitam para passar suas mensagens ao público e detonar todo o tipo de ação promocional - distribuição de brindes, descontos na compra de seus produtos, sorteios de torcedores para dar o pontapé inicial, acompanhar o jogo do banco de reservas, ou bater um pênalti no goleiro do seu time etc. ${ }^{4}$

Para os torcedores mais fiéis detentores dos ingressos para a temporada -, uma surpresa: o sor- teio de três viagens para a partida de volta, em Milão, com todas as despesas pagas e direito a acompanhante. E, como este sonho é meu, não poderia dar outra: fui um dos escolhidos!

Ao final do primeiro tempo, o show continua: gols dos outros jogos da rodada e melhores momentos no telão, coreografias no campo, sessões de fotos com os mascotes dos times e do torneio e mais promoções!

Enfim, termina o jogo! Interessado em saber o resultado? Sinceramente, depois de um fim de semana repleto de bons momentos, até o mais fanático torcedor terá que concordar que o balanço será positivo, mesmo que o clube saia derrotado em campo.

Como diz a letra da música, "um sonho a mais não faz mal". Apesar de tudo, sou um otimista e acredito que, quando as pessoas que lidam com o esporte passarem a tratá-lo como entretenimento, sonhos como esses estarão bem próximos de se realizarem.

Obs.: Todos os nomes utilizados são fictícios.

\section{NOTAS}

1. O complexo usado para beisebol e futebol americano de Toronto inclui um hotel.

2. Uma das megastores mais famosas do mundo fica dentro do estádio do Manchester United (Old Trafford), que também conta com um museu interativo e um bar temático, o Red Cafe.

3. Uma linha de metrô deixa os torcedores dentro do estádio do Ajax de Amsterdã, que também conta com várias opções de alimentação.

4. As promoções durante as partidas são uma constante nas principais ligas profissionais norte-americanas de futebol americano (NFL), basquete (NBA), beisebol (MLB) e hóquei (NHL).

Luís Fernando Pozzi é Professor de Marketing Esportivo da EAESP/FGV e autor do livro A grande jogada: teoria e prática do Marketing Esportivo. 